\title{
THE FILM INDUSTRY IN LATVIA AS A POTENTIAL RESOURCE FOR TOURISM DEVELOPMENT
}

\author{
Kino nozare Latvijā - tūrisma attīstības resurss
}

\author{
Daina Vinklere, Ilze Kasa, Ingrida Ludzina \\ Turiba University, Faculty of International Tourism \\ e-mail: daina.vinklere@turiba.lv
}

\begin{abstract}
During a time of increasing competition in the tourism sector and growing demand for new tourism products, all stakeholders must more actively utilise non-traditional tourism resources. The film industry certainly counts as one of them. Although film-induced tourism has become quite popular round the world and maintains significant influence, these developments and research into this area have not gained enough attention in Latvia. The objective of this research is to examine the film industry as a tourism resource based on an analysis of the available public information on film production locations, related promotions for tourists in Latvia and the interest and experience of the general public in these types of tourist attractions. The results of the research prove the potential of the film industry, the existence of certain pieces of groundwork and at the same time the moderate interest of potential clients in engaging these resources and adding to Latvia's tourist turnover.
\end{abstract}

Keywords: creative industries, film industry, film-induced tourism, tourism resource, tourism product DOI: $10.22364 /$ fg. 18.7

\section{Introduction}

With the development of the tourism industry both globally and in Latvia there is increasing demand for new tourism products, which are understood as "goods, paid or free services, wealth, values and conditions or their totality created by human activity, which contain actual consumption value and which are created and adapted for satisfying the needs of tourists" (MoE 2008 294). With change in demand and increase of competition in the tourism industry, new types of tourism resources are engaged in the creation of innovative tourism products, which are understood as "a totality of natural and man-made factors and processes possessed by a tourism place and which attracts tourist interest" (MoE 2008 294). The film industry has become one of these kinds of tourist resources and is one of the most significant creative industries globally. The film industry, which has been defined in Latvia as a field of culture encompassing the production of Latvian films, the distribution of Latvian and foreign films, and ensuring the preservation, protection, availability and promotion of Latvia's cinematographic heritage (Film Law 2010) is increasingly coming to the forefront in Latvia, particularly after the stagnation of the 1990s. The normative documents developed to shape the industry (The Film Law, The Strategy of the Film Industry 2014-2020 et.al.) testify to this fact, as do the creation of an institutional structure responsible for the film industry, and state and municipal support for film production, including the production of foreign films. For instance, co-financing by the National 
Film Centre and Riga Film Fund provides for engaging six to seven foreign films annually. The National Film Centre provides $20 \%$ of the total eligible costs in cofinancing (if without an identifying reference to Latvia; $25 \%$ if a reference is included), Riga Film Fund provides $20 \%$ in co-financing if the shooting takes place in Latvia and $25 \%$ if it takes place in the administrative territory of Riga. The objectives of co-financing include the attraction of foreign film industry financing, the promotion of Latvian cultural exports and the promotion of Latvia's overall image internationally, the promotion of Latvia's creative industries, and the promotion of cultural tourism (National Film Centre of Latvia 2019).

Film-induced tourism is the most commonly used term in this context. According to Beeton (as cited in Hamn and Wang 2011) film-induced tourism refers to visits to sites where films and TV programmes have been filmed, as well as tours of production studios, including film-related theme parks. In this way, film-induced tourism has become a sub-form of cultural tourism, while a film production itself contributes to the use of infrastructure, including tourism infrastructure. It can become a marketing tool for the promotion and recognisability of a tourism destination (Beeton 2006; Juškelyte 2016; Hahm and Wang 2011) and simultaneously serves as a resource for the creation of new tourism products at a destination. Although still considered a new type of tourism (Cardoso et al. 2017), popular films can increase the flow of tourism to the filming location (either the actual filming location or a location where the storyline of the film took place) by $25 \%$ to $300 \%$ (Champion Traveler 2019). For instance, according to the data collected by Manson and Eskilsson, a year after the release of Braveheart, the number of visitors to the Wallace Monument (Scotland) had grown by 300\%, while within a few years of the release of the TV series Wallander turnover in the tourism sector of Ystad (Sweden) had gone from EUR 56 million to approximately 83 million and the number of full-time employees had increased from 338 to 560; furthermore, the TV series Heartbeat increased the number of visits ton Goathland, Yorkshire (England) by 7.5 times, creating new jobs in the local tourism sector, new hotels and product sales, and extending the tourism season (Nizol 2016). These facts lead to the conclusion that the development of the film industry and the improvement of international recognisability can be utilised more to increase visitor numbers at tourist attractions and to boost revenue in Latvia.

Cultural tourism and the creative industries enjoy a significant place in the tourism industry. Cultural tourism and the creative industries have been defined as ones of the four strategic types of tourism for Latvia and support programmes for the attraction of creative industries were established (MoE 2014). Proposals for the support of developing cultural tourism products, particularly targeted at internationally popular areas which are in line with the specific interests of Latvia, have been suggested for the new planning period (MoE 2019). EU experts have pointed to the increased development of synergies between creative industries and tourism and the good coordination and cooperation of the institutions involved as positive factors in 
Latvia (PROMAN Consortium 2016). However, compared to other countries, the potential of the film industry and its implementation in Latvia has not been utilised enough. The lack of significant research into the area testifies to this fact. This, in combination with the abovementioned factors, proves the topicality of the theme.

This research puts forward two subjects of research: 1) research into information available on the Internet on film production locations in Latvia and related promotions for tourists; 2) research into the experiences of residents of Latvia and their interest in visiting tourism destinations and sites related to film productions. Answers to questions on these subjects may assist professionals in deciding on the creation of new tourism attractions and travel routes.

\section{Data and methods}

The empirical part of the work applies the paradigm of pragmatism by using both qualitative and quantitative research methods. By employing the method of document analysis, the authors collected and summarised information available on the Internet on various (Latvian, co-produced and foreign) film production/shooting locations in Latvia as well as the related existing tourism promotions. This information was acquired by using Google search and entering various theme-compliant keywords, thus gaining access to various sites containg relevant data. A questionnaire survey was used, employing the principle of random selection to learn the opinions of Latvian residents. The questionnaire was posted on webanketa.com, on social networks and was also communicated at a personal level by employing the "snowball' method. The activities resulted in 160 completed questionnaires, which, despite not providing sufficiently high credibility, characterise the situation to a certain extent. The questionnaire contained 15 questions, including four open questions on visiting filming locations.

The research was conducted in October 2019.

\section{Results}

The research of information available on the Internet on various filming locations in Latvia resulted in the collecting and summarising of information on 106 films shot in Latvia (feature films, TV series and documentaries) and the conclusion that the majority of such places are located in Kurzeme (43\%) or Vidzeme (36\%) regions, while the smallest number of filming projects (or information about them) have been implemented in Zemgale (5\%) and Latgale (3\%) regions. Three of these films were shot before 1940, 56 during the so-called Soviet period (1941-1990) and 46 from 1991 onwards, thus reflecting the latest two historical periods quite similarly in terms of numbers.

Several tourism promotions were identified based on collecting and summarising information available on the Internet on tourism promotions related to filming locations and events. The cinema town Cinevilla represents the most vivid example of a film-induced tourism attraction implementing film production/shooting 
projects and serving as an interesting site for tourists and a tourism promotion developed over the last few years (Tukuma TIC 2019; Cinevilla Studios 2019). There are other positive examples as well. The project "Cēsis - Kino identitāte", which can be found at the directory of cultural environment trails in Latvia on the website letonika.lv, includes TAKA, a film map featuring 75 sightseeing places related to the shooting locations of popular films in Cēsis region (Letonika 2019). The website parkulturu.lv offers a map with the locations of Latvian films shot in Kekava region, including Zvejnieka dēls (A Fisherman's Son 1940; 1957), Bermontiāda (War Against Bermont 2009), Mājup ar uzvaru (Home with a Victory 1947), Salna pavasarī (Late Frost 1955), (Parkulturu 2019). The guesthouse Ezermaḷi offers visitors a chance to enter into the world of Ezera sonāte (1976) (A Lake Sonata 1976) (Ezermali 2019). The farmstead Ielīcas, just off the Valka-Smiltene highway, is a cultural-historical monument and is being promoted to tourists as a shooting location for the Latvian film Pūt, vējiņi (Blow Wind 1973) (Ziemeḷlatvija 2019). Kuldīga also promotes film production/shooting locations in the surrounding region (Kuldiga: History. Events. People database (2019)), while Madona tourist information centre organises trips to sites which, inter alia, include two places designated as tourism destinations - Kalna Jaunzemji and Dobulıi - as shooting locations for the Latvian TV series Likteña lìdumnieki (The Clearers of Fate 2008) (Madona TIC 2019). It has been reported in the media that Riga Film Museum has created a map of trails connected to Riga films, providing the opportunity to take a trip around Riga as a city of cinema and to trace the shooting locations of around 40 films, produced both during the Soviet period and recently (LSM 2014). However, it cannot be found on its website. The acquired results show that there exists a corresponding tourism promotion, including shooting locations of films from various periods, which can accordingly attract various target audiences of different age groups or could create a necessity for additional explanations. Overall, tourism utilises only a small part of the potential contained in the film industry. Besides the aforementioned sites, which are most attractive to Latvian residents, there are also several positive examples in the context of foreign films. For instance, the city of Liepāja has used its Internet resources for the promotion of filming activities in Liepāja and its surroundings in 2017 for the plot of a French TV weekend show, Echappées Belles, shot at Karosta (former military port), as well as a Japanese TV show, ITteQ: Let's Challenge the World, which has an average number of viewers of around 20 million and was shot at the same location (Liepājniekiem 2019). Places like these could be potentially interesting and utilised more actively for tourists of these respective countries during their visits to Latvia.

A survey of Latvian residents was carried out to gain insight into the extent to which activities related to filming could be used as a resource for attracting tourists to Latvia, as well as the etent to which sites related to filming are motivations for travelling. In total, $63 \%$ out of 160 people surveyed were women, and $37 \%$ were men, while the respondents were divided by age structure as follows: $22 \%$ were aged 18 to 
$30,61 \%$ were aged 31 to 45 and $17 \%$ were 46 or older. The frequency of travel indicated by the respondents was at least one trip per year. The statement that films did not have any effect on the motivation of travellers to visit a tourism destination was strongly disagreed with by $23 \%$, disagreed with by $63 \%$, agreed with by $16 \%$ and strongly agreed with by $0 \%$ of respondents. This, as well as many international examples, testify to the fact that tourist attractions like these have the potential to assert themselves as an important factor in selecting a destination. At the same time, $67 \%$ of respondents provided a negative answer to the question as to whether they had travelled to a destination they had seen in a film, which could indicate either lack of interest or the absence of suitable promotions. Respondents were asked an open question: where they would choose if they could travel to any location outside Latvia they had seen in a film. The most popular destinations were New Zealand (17\%) - on some occasions specific films such as Lord of the Rings and The Children of Captain Grant were also indicated as having inspired the choice and provided motivation for travelling - and the USA (13\%), with such destinations as Las Vegas, Hollywood film studios and New York being specified. Croatia was always named as a destination thanks to the series Game of Thrones, while Scotland on several occasions was associated with Braveheart, and Turkey was singled out thanks to the TV series Magnificent Century. Other countries named by respondents included Australia, France, Russia, England, Thailand, China, Canada, Ireland and Greece, as well as Antarctica.

To acquire more substantial replies regarding the factors motivating travellers to choose one or another travel destination based on their impressions from films, a question was asked about the most significant reasons for visiting a particular destination.

Table 1. The motivating factors of travellers for visiting filming locations (authors' figure)

\begin{tabular}{|c|c|c|c|c|c|}
\hline & \multirow{2}{*}{\multicolumn{2}{|c|}{\begin{tabular}{l|l} 
Minor reason & Quite an unimportant
\end{tabular}}} & \multirow{2}{*}{ Not an important at all } \\
\hline$\equiv 8: \because \equiv$ & The most important reason & Medium important reason & & & \\
\hline \multirow[t]{2}{*}{ Landscape } & & & - & & \\
\hline & $65.63 \%$ & $6.25 \%$ & $9.38 \%$ & $3.13 \%$ & $15.63 \%$ \\
\hline \multirow[t]{2}{*}{ Actors } & $\bullet$ & & & . & \\
\hline & $15.63 \%$ & $6.25 \%$ & $39.06 \%$ & $9.38 \%$ & $29.69 \%$ \\
\hline \multirow{2}{*}{ Story } & ? & & $\bullet$ & . & - \\
\hline & $23.44 \%$ & $31.25 \%$ & $17.19 \%$ & $7.81 \%$ & $20.31 \%$ \\
\hline \multirow[t]{2}{*}{ Destination marketing campaigns } & $\bullet$ & - & (2) & O & P \\
\hline & $14.06 \%$ & $10.94 \%$ & $23.44 \%$ & $26.56 \%$ & $25 \%$ \\
\hline \multirow{2}{*}{ Special movie tours } & - & - & $\bullet$ & - & \\
\hline & $12.5 \%$ & $12.5 \%$ & $15.63 \%$ & $23.44 \%$ & $35.94 \%$ \\
\hline
\end{tabular}

Assessing the replies summarised in Table 1, one can conclude that landscapes (nature sites, cityscapes, et.al.) represent the most significant reason for visiting a location seen in a film. The overall storyline (i.e. the motivation for travel is due to an emotional bond with a storyline of a film, while visual landmarks are not that significant) was the next most significant factor. Other important factors include the 
cast of actors of a film (respondents find it important to identify with a place that popular personalities are associated with. Marketing campaigns for specific destinations have also been mentioned as a significant motivator, allowing places to identify themselves with the film in question, while film tours dedicated to a specific film and delivered in the form of organised trips to all the filming locations of a film were referred to as the least significant. Besides, one of the respondents pointed out that a location seen in a film would not be the main destination, but rather one among a number of other destinations during a trip. The importance of the factors named by the respondents should be taken into account for promoting the development of filminduced tourism, and creators of tourism attractions and travel organisers should also bear them in mind.

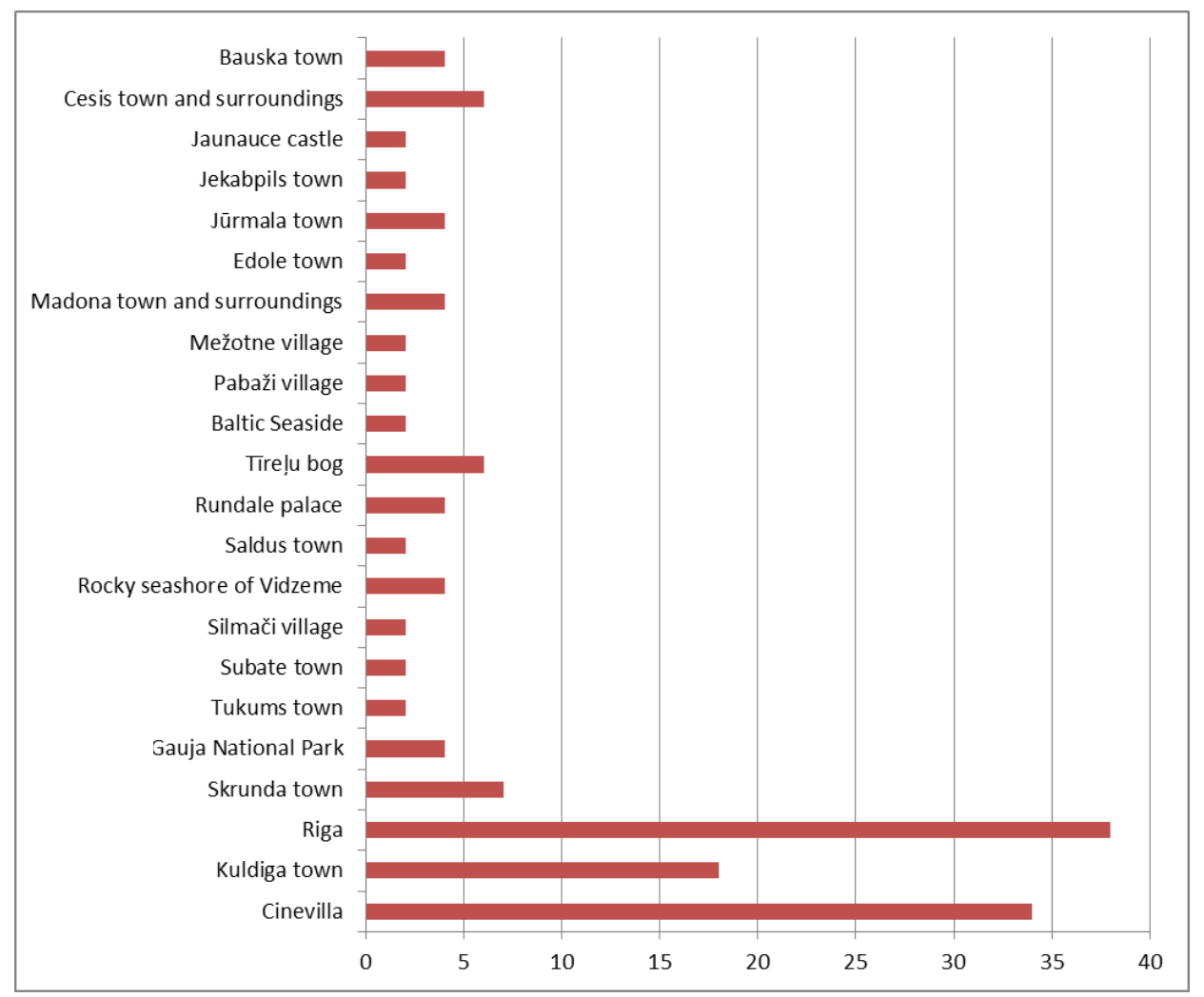

Figure 1. The filming locations in Latvia indicated by the respondents (authors' figure)

The next part of the questions dealt with films shot in Latvia. Answers to an open question as to what filming locations in Latvia were known to the respondents are summarised in Figure 1. It can be seen that Riga was named most often (38 reponses) while as filming locations Cinevilla received 34 responses, and the town of Kuldīga 18 responses, mostly citing the film "Emila nedarbi" (Naughty Emil 1985). Only seven respondents indicated that they did not know any filming locations in Latvia. In total, 58 filming locations were mentioned, with most of them only being mentioned once. It is interesting to compare these responses with replies to the 
question regarding which destinations the respondents have visited as filming locations and locations seen in Latvian films.

Table 2. Filming locations in Latvia visited by the respondents

\begin{tabular}{|l|c|}
\hline \multicolumn{1}{|c|}{ Places visited } & Number of answers \\
\hline Riga (incl. specified sites such as the Old Town, Ķengarags, etc.) & 12 \\
\hline Cinevilla & 9 \\
\hline Kuld̄iga & 7 \\
\hline Cēsis and surroundings & 7 \\
\hline Edole town & 2 \\
\hline $\begin{array}{l}\text { Tukums town, Zlekas village, stony seashore of Vidzeme, Jaunpils } \\
\text { town }\end{array}$ & 1 \\
\hline $\begin{array}{l}\text { Jēkabpils town, Saulkrasti town, Carnikava village, Turaida town, } \\
\text { Aglona town, Liepāja town, Dundaga town }\end{array}$ & \\
\hline
\end{tabular}

It should be mentioned that only 41 answers were received to this open question, and 16 destinations (which have been grouped into larger territorial units) were mentioned by respondents. The results of the survey reflected in Table 2 lead to the conclusion that only a small number of filming locations have been visited as filming locations and there is space for development for using the film industry as tourism resource in future.

\section{Conclusion}

Summarising the results of this research, one can conclude that there are many examples globally of successful use of the film industry in the development of tourism destinations, thus increasing the desire of viewers to travel to places where films have been produced/filmed or that are featured in the cinematography and therefore providing a significant contribution to tourism and the economy in general. Latvia also has good preconditions for the use of the film industry in tourism, particularly taking into account the Soviet heritage in this area and the achievements of the past few decades. Overall, Latvia lacks targeted tourism promotions related to the film industry, the public information available is fragmented, and only a few locations have been developed as specific products for cultural tourism. However, there are several successful film-related tourism promotions. As reflected in the survey of Latvian residents, there is moderate interest and insufficient knowledge regarding the opportunities and benefits of visiting such sites, thus testifying to the insufficient use of their potential. The results of this research reflect the existence of promotions and the availability of information on the Internet. However, more detailed research would be required to assess the quality and the intensity of the use of the respective sites as tourist attractions. Municipalities and businesses can make use of the results of this research to carry out a critical assessment of the information available about filming locations in Latvia and the opportunities to create a tourism product that would correspond to this theme in terms of its design and contents and place it on tourist- 
oriented websites, together with objective and attractive information on filming locations that relate to a particular story. Municipalities and businesses could also consider how to make use of foreign films with internationally acclaimed actors in order to promote Latvia or a specific location, and as a result, attract foreign tourists.

\section{Kopsavilkums}

Laikā, kad tūrismā arvien palielinās konkurence un pieprasījums pēc jauniem tūrisma produktiem, nozarē iesaistītajām pusēm arvien aktīvāk jāizmanto netradicionāli tūrisma resursi, par kādu var uzskatīt arī filmu nozari. Lai gan daudzviet pasaulē filmu izraisīts tūrisms ir kḷuvis gana populārs un tā ietekme ir ievērojama, Latvijā šīs jomas attīstībai un pētījumiem nav pievērsta pietiekama uzmanība. Šī pētijuma mērḳis ir apzināt filmu nozari kā tūrisma resursu Latvijā, izvērtējot pieejamo informāciju interneta vidē, uz filmu uzņemšanas vietu un notikumu bāzes izveidotos tūrisma produktus kā piemērus šì resursa izmantošanai, kā arī izzināt Latvijas iedzīvotāju pieredzi un ieinteresētību šāda piedāvājuma izmantošanā. Pētījuma rezultāti parāda filmu nozares potenciālu, jo pastāv filmu un tūrisma nozares pozitīvas stratēǵiskās nostādnes, ir vairāki labi piemēri un vienlaicīgi mērena potenciālo klientu ieinteresētība šo resursu iesaistei tūrisma apritē Latvijā.

\section{References}

Beeton, S. (2006). Understanding film-induced tourism. Tourism Analysis, 11, 181-188.

Cardoso, L., Estēvāo, C., Fernandes, C. and Alves, H. (2017). Film-induced Tourism: a systematic Literature Review. Tourism \& Management Studies, 13 (3), 23-30.

Cinevilla Studios (2019). Cinevilla Studios. http://www.cinevilla.lv (01.10.2019).

Champion Traveler (2019). Popular Movies Can Increase Tourism to the Film's Location between 25\%-300\%. https://championtraveler.com/news/popular-movies-can-increase-tourism-to-the-filmslocation-between-25-300/ (09.10.2019).

Kuldiga: History. Events. People database (2019). Movies. http://www.mantojums.kuldiga.lv/filmas/ (15.10.2019).

Ezermal̦i (2019). Ezermaḷi. http://www.ezermali.lv/ (01.10.2019).

Film Law (2010) Latvijas Vēstnesis, 101. https://www.vestnesis.lv/ta/id/212399-filmu-likums (01.10.2019).

Hamn, J. and Wang, Y. (2011). Film-inducted tourism as a vehicle for destination marketing: is it worth the efforts? Journal of Travel \& Tourism Marketing, 28, 165-179.

Juškelyte, D. (2016). Film induced tourism: destination image formation and development. Regional Formation and Development Studies, 2 (19), 54-66.

Madona tourism information centre (2019). Madona tourism. http://visitmadona.lv/lv/jaunumi?fu=read\&id=792 (02.10.2019).

National film centre of Latvia (2019). Lïdzfinansējuma fonds ārvalstu filmām. http://nkc.gov.lv/finansejums/lidzfinansejuma-fonds (10.10.2019).

Niziol, A. (2016). Film tourism as a new way to market a destination. Scientific Review of Physical Culture, 5 (4), 149-156.

Latvijas sabiedriskie mediji (LSM). (2014). Latvijas filmu vēsture ieklauta jaunā Rīgas kino kartē. https://www.lsm.lv/raksts/kultura/kino-foto-un-tv/latvijas-filmu-vesture-ieklauta-jauna-rigas-kinokarte.a103465/ (02.10.2019).

Letonika (2019). Taka: kino karte. https://www.letonika.lv/groups/default.aspx?title=3572ab243c58-4372-9c9a-2153caddb811 (01.10.2019).

Liepaja municipality (2019). Liepāja liepājniekiem. https://www.liepaja.lv/liepajniekiem/ $(01.10 .2019)$. 
Ministry of Economics of the Republic of Latvia (MoE) (2014). Guidelines of Latvian Tourism Development 2014-2020. Rīga: Ministry of Economics.

Ministry of Economics of the Republic of Latvia (MoE) (2019). Proposals for the 2020-2027 action plan for the development of Latvian tourism supply. Development of an action plan for the development of the Latvian tourism supply within the framework of the INTERREG Europe project BRANDtour.

Ministry of Economics of the Republic of Latvia (MoE) (2008). Türisma un viesmìlības terminu skaidrojošā vārdnīca. Rīga.

Ministry of Culture of the Republic of Latvia (MoC) (2018). Film Industry Strategy for 2014 2020.

PROMAN Consortium (2016). Mapping exercise: How could creative industries foster innovation in tourism in the northern dimension area? Country report- Latvia. RfS 2015/369412/1.

Tukums tourism information centre (TIC) (2019). Kino vietas. https://www.visittukums.lv/lv/Koskatit/Kino-vietas (15.10.2019).

Ziemeḷlatvija (Northern Latvia) (2018). Ciemos zemnieku sētā "Ielīcas”, kur tapa leǵendārā filma "Püt, vējiņi". $\quad$ https://www.ziemellatvija.lv/dzivesstils/ciemos-zemnieku-seta-ielicas-kur-tapalegendara-filma-put-vejini-137266 (01.10.2019). 